\title{
“À SOMBRA DAS RAPARIGAS EM FLOR” \\ A Faculdade de Filosofia da Universidade de Minas Gerais
}

Maria José de Queiroz

UFMG

1953... 2008. Faz cinquenta e cinco anos...

Depois de festejar os seus setentanos em abril, Getúlio Vargas comemoraria em 3 de outubro de 1953 o terceiro aniversário do pleito que o conduzira à presidência da República. Para conferir à data a aura das efemérides, sanciona, no mesmo dia, a lei da criação da Petrobrás, anunciando-a, urbi et orbi, em cadeia radiofônica.

Destinada a solucionar o maior entrave ao progresso da indústria brasileira, a estatal inaugurava com direitos de monopólio uma nova era no país: a da exploração e produção do petróleo. Era o que todos pediam. Não obstante, nem a importância cívica do ato, nem o sortilégio mítico da coincidência cronológica lograram desanuviar os espíritos.

Pairava sobre a solenidade a sombra espessa de ressentimentos mal resolvidos desde o fim da ditadura. Embora imprevisível, o destino do país haveria de decidir-se ali, entre o Palácio do Catete e o Palácio Tiradentes, onde se debatiam os fins do Estado e os valores da democracia.

Instaurado no domínio parlamentar, cujo instrumento de repercussão era a imprensa, o processo do Executivo e do Legislativo seguia seu curso. Enquanto isso, o circo e a rotina entretinham, na periferia do poder, os caprichos dos áulicos. Assim é que, Mantiqueira acima, se cuidava, sem reserva, das comemoraçóes dos cinquenta e seis anos de fundação da capital de Minas.

Herdeira do arraial "Belo Horizonte", a nova cidade honrava-lhe o nome: nosso horizonte nada tinha de feio. Nem de triste. Ainda não...

Ao pé do cruzeiro (não o bairro, mas a cruz plantada no topo da encosta por onde descia o mesmo "ar arejado" que respiraria Mário de Andrade), divisava-se, soberba, a Serra do Curral d'el-Rei (que já não se vê e apenas se nota).

Nada disso nos interessava.

Alheios à confrontação política, que só faria crescer até 1954, uma coisa, de máxima grandeza, nos preocupava: o vestibular. Para isso, e por isso, queimávamos as meninges, tomávamos Pervitin, Adjuvex, Coca-Cola com café...

Éramos nove. Nove meninas em flor. O vestibular de 1953 nos reuniria no "bolode-noiva", o prédio cor-de-rosa da velha Escola Normal, entre Timbiras e Carandaí. Depois de provas orais e escritas de latim, português, francês e inglês, voltaríamos a encontrar-nos: éramos calouras.

A Faculdade de Filosofia (Filosofia, Ciências e Letras) distribuía-se, sem atrito, do décimo-nono ao vigésimo-primeiro andares do Edifício Acaiaca. Ali mesmo onde 
São José pontifica, cara a cara com os indígenas, tendo aos pés a verde e copada Afonso Pena, Tamóios desaguava rumo ao Parque e a Santa Teresa, enquanto Espírito Santo, a Wall Street mineira, arrastava as enxurradas de Lourdes ao Arrudas - fiozinho tranquilo ou lamaçal revolto - sempre acanalhado.

Embora os professores não tivessem "barbas brancas", a "escola", a nossa escola, era, sim, "risonha e franca". E os funcionários da Secretaria, Denakê, Messias Donato, Sr. Alexandre, Dirce, Hortência, Nílvia, Lená, Guido, José Muriel e Washington, tanto como Elisabeth Vorcaro Horta e Afrânio França, na Biblioteca, tudo faziam para alinharse aos versos da nossa infância.

Preservadas as diferenças curriculares, integrávamos um clã; melhor, uma clerezia. Alheios, todos, ao tumulto do centro comercial e bancário da cidade, nos isolávamos na nossa torre. A altura do prédio não nos dava vertigens nem nos impedia de chegar, a tempo e hora, às salas de aula: vencíamos, sem caimbras, vinte, vinte e um andares, quando as tabuletas "Parado" / "Manutenção" nos convidavam à escalada.

No dia 7 de março de 1953, festa de São Tomás de Aquino, patrono da filosofia, subimos ao vinte-e-um para a Aula-magna. Os elevadores funcionavam. Aprovadas e matriculadas, responderíamos, no dia seguinte, à chamada (porque havia, é óbvio, diário de classe e frequência obrigatória).

O Curso de Letras Neolatinas ocupava as salas imediatas à Diretoria, em toda a extensão da ala direita do dezenove. A cada Presente!, um sorriso de boa acolhida aos nomes de Elaene Marilza Fernandes Varella, Marlene Machado Zica, Maria José de Queiroz, Maria Martha dos Reis, Maura Borges de Andrade, Norma do Carmo Alvarenga, Regina Bastos Pereira, Terezinha Loureiro e Terezinha Lopes da Costa. A terceira Terezinha, Terezinha Alves Pereira, "a Loura de-cá”, abandonaria o curso no segundo ano letivo para retomá-lo anos mais tarde.

Desse grupo, cordialmente unido, faziam parte ex-alunas do Colégio Estadual (antigo Ginásio Mineiro), do Instituto de Educação e do Colégio Sacré-Coeur de Marie. José Lourenço de Oliveira, nosso professor de latim, apelidou-nos "As infalíveis". No próprio e no figurado...

Embora tivéssemos dois colegas e um deles nos haja acompanhado, dia-a-dia, até a colação de grau, apenas nos falávamos. Arredios, mantiveram, ambos, com as Infalíveis, a mais amena incomunicabilidade. Ao dirigir-lhes nossas saudações, não ouvíamos em resposta mais do que vago murmúrio. E deles nada soubemos senão que, determinados, buscavam êxito nos exames e a aprovação no fim do ano.

Tentamos, em vão, quebrar o gelo que nos separava. Fizemos caminho à parte. Tudo terminou bem. Entre nós, o bando feminino, jamais houve rixa, desentendimento ou mesquinharia. A alegria e a desenvoltura, próprias da idade, não nos impediram o mais natural acato à disciplina universitária. Cumpríamos com exação as tarefas. Solícitas, atentas, raramente nos ausentávamos. Postadas nas primeiras filas, acompanhávamos em silêncio as preleções. Só abandonávamos as carteiras pra ver a banda passar.

Éramos infalíveis. De fato. Excepcionalmente, num dia aziago de agosto, em 54, corremos, sobressaltadas, à sacada. Um atropelado corre-corre, abafado por gritos e alarme, repercutira na sacada a notícia do suicídio, ou assassínio, no Rio, do presidente Vargas... 
Como continuar a assistir à aula de Português, ainda que de Mário Casassanta? Foi então que iniciamos, ao ritmo do rock and roll, doses de Cuba libre e discursos de Evita, o aprendizado da retórica política, das sutilezas da demagogia e do charme, indiscreto, da ideologia marxista.

A "nossa América” estremecia...

Sobrevivemos.

No quarto ano de convívio cordial e prosseguido, a licenciatura encarregou-se de dispersar-nos no auditório do vinte-e-um, a que acorriam alunos dos demais cursos da Faculdade. Cursos magistrais (no sentido próprio do termo) mas de sagrada confraternização. Germinal nunca respondia Presente! à chamada da professora de Didática. Do fundo do salão, baritonava: "Louvado seja Nosso Senhor Jesus Cristo, Dona Filó!”

Esquecer... quem há-de?

Mas uns e outros - futuros matemáticos, biólogos, cientistas sociais, psicólogos, pedagogos, geógrafos, historiadores, físicos, químicos, humanistas, filósofos e literatos sairíamos todos da licenciatura com o diploma de professor e o registro em carteira do MEC. Sob tão bons auspícios, concluiu-se com êxito nossa iniciação à vida e à sua imagem. Estávamos habilitados ao exercício do magistério: aptos a fazer caminho ao andar...

Mais, muito mais do que em História, ou Histórias da Literatura, de farta hermenêutica e rica documentação biográfica, cronológica e sinóptica, de ecdóticas e semióticas, tudo bem lastreado em terminologia hermética, em voga na época, ${ }^{1}$ fomos instruídos, de Café Filho a Kubitschek, na filosofia das literaturas.

Assim sendo, nem éramos, os alunos, estudantes típicos de uma Faculdade de Letras, nem nossos professores se comportavam como experts de plantão. E o melhor: eles nos ensinavam o que não nos ensinavam...

Haveria melhor maneira de encarar o mundo em fase tão conturbada? Como conciliar populismo, aliança pessedista, deposição de um presidente com o Sine ira ac studio das aulas de latim? Na esteira da miragem de Brasília, como ignorar a marcha para o Oeste e o convite à viagem na voz do visionário de Diamantina?

Era outra nossa marcha. E de igual urgência. Se permitido fosse comparar o que se passava na Fafi, com o que se construía Brasil adentro, glosaríamos JK: fizemos "quarenta anos em quatro".

E razões não nos faltavam.

Egressos das Faculdades de Direito, de Medicina e de Engenharia, do velho Caraça e da Escola de Minas de Ouro Preto, superiormente credenciados a qualquer cargo universitário, os nossos mestres empenhavam-se em superar-se nas novas funções. Entre os brasileiros natos, com obra publicada, pesquisas ou trabalhos realizados, contavamse, no corpo docente, um Alcides Ferreira, um Miguel Maurício da Rocha, um Edmundo Menezes Dantas, um Eduardo Schmidt Monteiro de Castro, um José de Carvalho Lopes, um Francisco de Assis Magalhães Gomes e, também, José Oswaldo de Araújo, Milton Campos, Eduardo Frieiro, Arthur Versiani Veloso, Sylvio Barata, Maria Luísa de Almeida

${ }^{1}$ Leia-se o poema de Carlos Drummond de Andrade, "Libera nos domine". 
Cunha, José Lourenço de Oliveira, Arduíno Bolivar, Cláudio Brandão, Lair Remusat Rennó, Waldemar Versiani dos Anjos, Cônego José de Sequeira, Padre Pedro Vidigal, Padre Orlando Vilela, Tabajara Pedroso, Manuel Casassanta, José Pelegrino (pai de Helio Pelegrino), Abgar Renault, Alísson P. Guimarães, Aires da Matta Machado Filho, Mário Casassanta, Emanuel Brandão Fontes, João Camilo de Oliveira Torres, Aída Costa, Orlando M. de Carvalho, Alaíde Lisboa de Oliveira e José Carlos Lisboa... Excusez du peu! Plêiade jamais reunida numa única congregação.

Entre cidadãos residentes ou naturalizados, ainda havia ninguém menos que a russa Helena Antipoff (ex-discípula de Claparède); italianos, como o escritor Vincenzo Spinelli, poderoso intérprete de Dante e sua obra, o cientista Giorgio Schreiber e Maria Schreiber, professora de italiano; franceses, como o normalien Maurice Vouzelaud, o geógrafo Pierre Monbeig, além dos Teullières, Senhor e Senhora, e Jean Vincent e Pierre Venot, contratados pela Alliance Française; suíço, como Marcel Debrot; espanhol, como José Quiroga Carballada; escossês, como Ian Linklater; alemães, como o Padre Goetze e o filósofo Ansorg, ou, de origem germânica, como Frau Kux, davam o melhor de si na formação dos estudantes. Isso significava, em ordem de clerezia, fazer face a conceitos fundamentais do conhecimento cujos tratados nada têm a ver com os manuais de classe nem com as gramatiquinhas escolares.

Visto que pertencíamos à quarta geração de alunos da Faculdade de Filosofia, tivemos como professores, já no "Cursinho", oferecido pela Faculdade, ali mesmo, no Acaiaca, alguns dos seus mais brilhantes alunos. Entre os quais: D. Ângela Tonelli Vaz Leão, professora de português e D. Solange Ribeiro de Oliveira, de inglês. Nos anos seguintes, viríamos a conhecer e estimar outros ex-alunos, oportunamente integrados ao corpo docente. A saber: Fernando de Freitas, Wilton Cardoso de Sousa, Alita Sodré, Rubens Costa Romanelli, Pedro Parafita de Bessa, Luís Bicalho, Amaro Xisto de Queiroz, Morse de Belém Teixeira, Lyncoln P. de Bessa, Maria Luísa I. Bandeira de Mello, Getúlio Vargas Barbosa... Sobreleva ainda assinalar que nos quatro anos de nossa permanência na Faculdade, os professores Maria Luísa Ramos e Wilton Cardoso de Sousa se apresentariam a concurso de livre docência para a cátedra de Literatura Portuguesa. Em exames públicos, de grande repercussão, patenteou-se a excelência da formação dos candidatos. Assistimos, durante as defesas de tese, a verdadeiros torneios de inteligência, conhecimento e domínio da matéria.

Caso singular foi o do escritor Eduardo Frieiro, autodidata. Nas funções de redatorchefe da Imprensa Oficial, haveria de ocupar-se, em 1930, da editoração do primeiro livro de Carlos Drummond de Andrade. ${ }^{2}$ E ainda: além de incumbir-se da composição e diagramação de Alguma poesia (a que Medeiros de Albuquerque não recusaria elogios num artigo ferino - Alguma tipografia), o mestre tipógrafo propiciou a Drummond o uso do selo Pindorama, nome da editora por ele inventada.

\footnotetext{
${ }^{2}$ Em nota a uma carta de Mário de Andrade, Drummond revela: "Depois de dar um trabalhão ao MA, acabei publicando meu livro Alguma poesia pela Imprensa Oficial de Minas Gerais, a preço camarada, pagando-o parceladamente" (A lição do Amigo. Cartas de Mário de Andrade a Carlos Drummond de Andrade. Rio de Janeiro: José Olympio, 1982, p. 148, carta de 02/05/1930, n. 1).
} 
Após o aparecimento de O clube dos grafômanos (1927), O mameluco Boaventura (1929), Inquietude, melancolia (1930), do mesmo Frieiro, e de República Decroly (1935), de Moacir Andrade, as edições Pindorama cederiam lugar à Sociedade Editora Os Amigos do Livro, nova criação do incansável editor. ${ }^{3}$

Devem-se portanto a esse autodidata inigualável - romancista, ensaísta, professor universitário, erudito - não só o "Imprima-se" à primeira obra do nosso grande poeta, como o apuro gráfico da Editora Os Amigos do Livro, responsável pelo lançamento, em 1934, de Brejo das almas. O êxito dessas iniciativas, assim como a repercussão de seus ensaios e romances, passaram a credenciá-lo, amplamente, a qualquer posto no domínio da cultura.

E foi o que aconteceu. Rubens Borba de Morais convidou-o a assumir a diretoria da Biblioteca Nacional. Arredio, "urso cavernícola", como se confessava, Frieiro recusa, de pronto, a honraria. Mas a esse convite haveria de suceder o apelo insistente dos fundadores da Faculdade de Filosofia, propondo-lhe a regência da cátedra de Literatura Espanhola. Depois de hesitações e delongas, curva-se ele, muito a contragosto, à exigência burocrática de recurso ao Ministério da Educação a fim de obter, pro forma, o título de acesso ao magistério superior.

Tudo se passa como previsto. O Senhor Ministro não faz senão ratificar o que era de domínio público: o "Notório Saber" de Eduardo Frieiro. Isso posto, autoriza o registro imediato do diploma, exigido e excepcionalmente concedido, para o exercício de cargo universitário.

A exemplo de Luís da Câmara Cascudo, gênio tutelar do Nordeste, Eduardo Frieiro jamais deixaria Minas Gerais. E contribuiria, de maneira generosa, para que na nossa escola figurasse, na sua integridade harmônica, a diversidade acadêmica. Ao receber a incumbência de projeto e composição de uma revista universitária, capaz de representar, com pompa e circunstância, a recém-criada Faculdade de Filosofia, Frieiro dedicou-se, exemplarmente, à sua tarefa.

Tipógrafo de formação, amigo dos livros e aficionado à leitura de revistas francesas, italianas, espanholas, alemãs e argentinas, e também assinante dos grandes periódicos internacionais, pôde ele programar e formatar, à perfeição, a revista da Faculdade.

Um primor do savoir-faire do nosso mestre-tipógrafo!, exclamaria Arthur Versiani Veloso ao receber a boneca do primeiro número. Capa gráfica de branco imaculado, à Diogène, costurada e brochada, a Kriterion distinguia-se pela elegância e sobriedade. Seu criador e diretor, fielmente assistido por Theobaldo Oppa, soube mantê-la viva, com irrepreensível nomeada, dentro e fora do Brasil. ${ }^{4}$

\footnotetext{
3 "Escrever é fácil. Imprimir o que se escreve, nem sempre o é", dizia Frieiro. E explica: "Em Minas, onde não existem ainda empresas editoras, os originais estão condenados a repousar eternamente no fundo das gavetas se os autores não os imprimem à própria custa nas nossas topografias roceiras" (Letras mineiras. Belo Horizonte: Os Amigos do Livro, 1937, XXII, p. 146).

${ }^{4}$ Igual consagração seria obtida pela Revista Brasileira de Estudos Políticos, criada em 1956 por Orlando M. de Carvalho, catedrático de Literatura Francesa, do Curso de Letras Neolatinas da Faculdade de Filosofia da UMG, e de Teoria Geral do Estado, da Faculdade de Direito da UFMG. Muito haveria de servir ao professor de TGE a experiência como diretor e fundador de O Correio do Dia, matutino mineiro, publicado em Belo Horizonte na década de cinqüenta. Sua revista logo se impôs como a mais abalizada publicação sobre estudos políticos da América Latina. Consultada e citada por eminentes especialistas universitários, tanto quanto por políticos e autoridades da administração pública, a revista da Faculdade de Direito sempre gozou de imenso prestígio e só deixou de circular ao desaparecimento do seu fundador.
} 
E não se creia que os aprendizes de literatura ficassem imunes à febre da letra de forma. De modo algum. Para combater o vírus, o Diretório Acadêmico recorreu à ciência dos homeopatas: inoculou nos doentes o mesmo vírus ao publicar-lhes os escritos na revista da Faculdade, a recém-criada Mural. ${ }^{5}$ Só então aprendemos o que Frieiro, versado em letras e nas suas misérias, já comprovara: "Quem se imprime se oprime". O pior? O mal era, e é, incurável.

Para conjurá-lo, o escritor escrevera A ilusão literária. ${ }^{6}$ Em vão. Pois não se dispondo, como Camilo Castelo Branco, nem a moer cana nem a serrar madeira, resignara-se a imprimir-se e a oprimir-se... Se bem que para deleite dos happy few que ainda o lêem, e relêem, tanto como para regalo de quem hoje o descobre nos sebos do Rio, de São Paulo, do Nordeste...

Pura verdade! E quem é mercador de edições raras, sabe que o nosso Frieiro é garimpado nas feiras e nos sebos do Nordeste tanto como nas bancas e nos passeios do Sul-Maravilha, onde os camelôs expõem sua literatura. $\mathrm{O}$ que prova que não se morre de todo. E que o sopro que animava a nossa escola teve alento suficiente para chegar ao século XXI.

Natural... Não aprendemos latim? Não frequentamos os clássicos? Não decoramos a frase de Terêncio - "Homo sum: humani nihil a me alienum puto" - na pronúncia reconstituída do professor Lourenço?

Esse seria, se quiséssemos, o lema da Fafi. Nas nossas aulas e conversas, praticava-se, sem luxo e sem pose, o verdadeiro humanismo. Não havia entre nós guetos intelectuais nem, tampouco, culto à parte, capelas para os gênios da física, da metafísica e das matemáticas. Alunos de "Humanas", "Ciências" e "Letras", discutíamos, animadamente, no corredor do dezenove, de pé, diante da Cantina da Tiana, onde Marilda se desvelava para servir-nos o cafezinho; à volta do livro de ponto dos professores; na sala diminuta do D.A. ou, mesmo, à porta da biblioteca, no vinte, e à entrada e à saída do auditório, no vinte-e-um.

Nossos assuntos? As aulas do professor Veloso, de Milton Campos, de João Camilo de Oliveira Torres, de Alcides Ferreira e de Chiquinho Bomba-Atômica - Francisco de Assis Magalhães Gomes, "dono" do reator atômico.

Uma das fábulas da Escola, fundador e diretor da Faculdade de Filosofia, mestre Veloso cumulara anedotário particular e dispunha de platéia cativa. Chamavam-no Velosão (por seu porte e peso) e havia quem o criticasse por dar aulas de Velosofia...

Seus numerosos e devotados discípulos, alunos regulares como estudantes de outras unidades, encarregaram-se de divulgar-lhe a fama de polígrafo excêntrico, misógino, beberrão. Sua nomeada começara nas salas do Marconi e do Ginásio Mineiro, onde o

${ }^{5}$ O primeiro número de Mural, Revista do Diretório Acadêmico da UMG, saiu em 1954. Foram seus diretores e secretários, sucessiva e respectivamente, nos anos de 1954 - Magda Becker Soares e Ítalo Mudado (ano 1, n. 1), 1955 - Evandro de Almeida Coelho e Maria José de Queiroz (ano 2, n. 2), 1956 - Ana Maria Viegas e Delauro Baumgratz (ano 3, n. 3).

${ }^{6}$ Belo Horizonte: Livraria Editora Paulo Bluhm, nova ed., 1941. Convite à meditação sobre os equívocos da literatura, o livro de Eduardo Frieiro respira a eternidade da palavra escrita ao mesmo tempo em que nos adverte acerca das penas e dos desastres que provoca. Obra-prima irretocável.

44 AletriA - v. 18 - jul.-dez. - 2008 
idolatravam. Se bem que precariamente instalada nas salas da Escola Normal, a Faculdade de Filosofia nimbou-o de glória e deu-lhe moldura própria, fazendo intervir inestimáveis elementos de psicologia pessoal, social e cultural.

Bom filósofo, Veloso procedia como os elefantes: jamais movia o segundo pé antes de firmar o primeiro. ${ }^{7}$ De degrau em degrau, o seu prestígio se irradiaria nesse mesmo passo: da cidade ao estado e do estado ao país. Isto é, dos ginásios à Universidade de Minas Gerais e, a partir de 1965, à Universidade Federal de Minas Gerais, com a sua escola registrada nos quadros do Ensino Superior da União, no Ministério da Educação e Cultura.

Todo esse trajeto se inscreve e situa-se em território preciso (os lugares da história a que se refere Pierre Nora): das salas do Colégio Marconi e do Ginásio Mineiro, no Ensino Secundário, à hospitalidade interina da Escola Normal, quando da fundação da Faculdade de Filosofia, em 1939, aos três andares do Acaiaca, já sob a tutela da UMG e, daí, até os sete andares do prédio próprio no Santo Antônio, onde ocorreria o posterior desdobramento da Faculdade de Filosofia em Faculdade de Filosofia e Ciências Humanas (Fafich), em 1968.

A cátedra e a imprensa converteram-no em figura pública. Seus artigos, de suma erudição, alongavam-se por semanas e meses a fio, para o prazer e perplexidade dos leitores. Inumeráveis, fanáticos mesmo, peripatéticos, comentavam-nos no Café Nice, na Afonso Pena, na Distribuidora Riccio, na Amazonas, e no bar do Inácio, na Bahia, e anos depois, na Goitacazes.

Era com inexcedível prosápia que o filósofo se investia, na intimidade do círculo de amigos, da grandeza metafísica. E com essa mesma prosápia, presidia, à imagem de Kant em Königsberg, ${ }^{8}$ as reuniões no Inácio, ponto de encontro, após 6 da tarde, de seus fiéis espectadores.

Para a celebração dos seus cinquenta anos, fomos despertá-lo a clarinadas. Mas não-contentes com a ruidosa alvorada, seus admiradores me pediram que lhe cantasse, ali mesmo, diante da janela da casa onde morava, à rua dos Aimorés, uma ária de Debussy, seu compositor predileto. À sua chegada ao balcão, espocaram fogos de artifício e ouviu-se, em seguida, a cantiga de aniversário de Vila-Lobos "Neste dia em que hoje comemoras..."

É força dizer: Belo Horizonte também era uma festa...

Ainda calouras, imaginávamos o mestre e filósofo da mesma linhagem de um Falstaff. Dele disse certa vez nosso colega Affonso Romano de Sant'Anna: "É figura de folclore". Em boa verdade, foi mais que figura de folclore: encarnou personagem de romance. O mestre-filósofo serviria de inspiração ao escritor e acadêmico Cyro dos Anjos, seu primo, para um dos seus livros.

Não, não nos faltavam, nos andares do Acaiaca, nem escritores, nem acadêmicos e poetas ilustres, nem vocações literárias, nem figuras caricatas à espera de quem os fizesse emergir do anonimato à fama.

${ }^{7}$ Não é outo o conceito de Fontenelle sobre o verdadeiro filósofo: "Os verdadeiros filósofos são como os elefantes, que, andando, não põem jamais o segundo pé no chão antes que o primeiro esteja bem firme” (Entretiens sur la pluralité des mondes, 1686, sixième soir).

${ }^{8} \mathrm{Na}$ sala da Diretoria, Veloso entronizara, por ocasião de sua posse, uma cópia do quadro de Kant e o círculo de Königsberg. 
Entre os estudantes, Lourenço Filho, Leão Cabernite, João Etienne Filho, Édison Moreira, José Nilo Tavares, José Olegário, Luís Rebelo Horta, Glaura Vázques de Miranda, Magda Becker Soares, Isaltina Goulart, Antonieta Bianchi, Ita Rebeca Waisberg, Jenner Procópio Alvarenga, Evandro Coelho, Márcio Quintão Moreno, Alvimar Bernardes, Wilson Camargos Assumpção, Guiomar Goulart, Francisco C. Ferreira da Silva, Laura Wanderley, Oneyr Baranda, Sami Sirial, Ydernéa e Hênio Morgan Birchal, Ítalo Mudado, Carlos Kroeber, Jonas Bloch, Dirceu Braz Fonseca, Vicente Abreu, Heitor Martins, Olinto Carlos da Fonseca, Antônio Sales, Teresinha Alves Pereira, Pierre Santos, Francisco Carlos Ferreira da Silva, Laura Wanderley, David Márcio, Pierre Santos, Nyelda, Maurício Gomes Leite, Affonso Romano de Sant'Anna e Silviano Santiago, muitos com carreira feita, outros, in progress, ou com o nome consagrado na imprensa, nas artes cênicas e nas profissões liberais, detentores de prêmios literários ou, ainda, com poemas ou artigos assinados nos periódicos mais representativos do país. ${ }^{9}$

É bom lembrar: tal como a geração anterior, a da revista Edifício, a geração

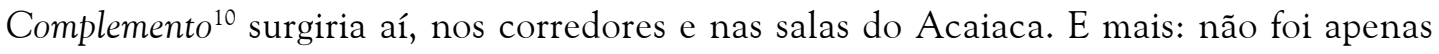
Veloso, o filósofo, que teve sua vida registrada nas páginas da literatura. Anos mais tarde, quando do lançamento de O grande mentecapto (1979), logo se propalou a notícia de que Geraldo-boi, louco manso, ex-seminarista (que não perdera o seu latim), se tornara protagonista de obra de ficção... Num romance de Fernando Sabino! ${ }^{11}$

Figura popular na cidade, soturno, polido, Geraldo filava almoço ou jantar com altivez e gravidade. Aproximava-se de professor ou aluno, que julgasse de alguma posse, e segredava: "Quer contribuir para o almoço?" E jamais infringia a regra a si mesmo imposta, de modéstia absoluta. Não havia, por isso, quem se recusasse a pagar-lhe um café, um Mate-Couro, um "bandejão” ou PF e, às vezes, um pé de porco no Tip-Top. Era querido dos estudantes e havia quem com ele revisse a Eneida ou De natura rerum.

Sempre a sobraçar jornais, livros e revistas, Geraldo era habitué das bibliotecas da cidade. Sentia-se em casa na Fafi: na cantina, no Diretório, nos três andares. De tempo em tempo, caía de amores por uma estudante ou funcionária. Conta-se que descobriram na sua mala, guardada no Almoxarifado, um livro de versos feceninos com referências nada católicas a uma de suas amadas. Personagem real? Ou fingimento só? Leiam O grande mentecapto.

Nossa curiosidade ia além, bem além da última conquista de Geraldo-boi. Tanto podia alcançar Les Mandarins, de Simone de Beauvoir, o último best seller de Françoise Sagan, a mais recente ficção de Jorge Amado, autografada na livraria de Édison Moreira,

\footnotetext{
${ }^{9}$ A partir da fundação, em 1952, de O Correio do Dia, cujo diretor era Orlando M. de Carvalho, nosso professor de Literatura Francesa, passamos a ter um jornal moderno, bem diagramado e com excelente parque gráfico, hospitaleiramente empenhado na promoção de jovens escritores. Foi assim que nossas mal traçadas linhas chegaram a publicar-se nos cadernos de maior prestígio de suas tiragens semanais.

${ }^{10}$ Revista de arte, cinema e literatura. Entre 1956 e 1958, publicaram-se quatro números. À geração Complemento, pertenceram, entre outros, Ari Xavier, José Nilo Tavares, Maurício Gomes Leite, Silviano Santiago, Teotônio Jr., Heitor Martins, Teresinha Alves Pereira, Ivan Ângelo, Décio de Castro, Ezequiel M. Neves e outros.

${ }^{11}$ Mas nessa ocasião, já estávamos no prédio da rua Carangola, na Fafich.
} 
no Dantés, como devassar a vida íntima de Marlene Dietrich, da voz rouca às pernas esculturais, admiradas "ao vivo", no Rio e em São Paulo.

A passagem do escritor Michel Butor pela Faculdade, a contratação interina de Manuel Rodrigues Lapa, o grande medievista português, perseguido por Salazar e refugiado em Belo Horizonte, os cursos ministrados por Albert Béguin, sobre o existencialismo francês, por I. S. Revah, sobre Gil Vicente, e por Joaquín de Entrambasaguas, sobre García Lorca, pelos professores de Coimbra, Lindley Cintra, Paiva Boléu, Costa-Pimpão e Agostinho de Campos, sobre a literatura, a língua e a história portuguesas, pelos professores da USP, Cruz Costa, Washington Vita e Eurípedes Simões de Paula, sobre filosofia e filosofia da história, e pelos professores da UFRJ, Thiers Martins Moreira e Afrânio Coutinho, sobre literatura brasileira e teoria literária, constituíam, sempre, motivo de orgulho para nós.

Responsável por convites aos luminares das letras, das ciências humanas e exatas, nosso diretor jamais poupava esforços para oferecer-nos em cardápios copiosos o que de mais refinado se servia lá fora, "no mundo civilizado". Sementeira de talentos, "sua" escola não podia manter-se fora do giro sabático dos scholars das grandes universidades européias e americanas. E tampouco permitia que se ignorasse a "prata da casa" - isto é, os colegas do Rio, São Paulo, Recife ou Porto Alegre...

Eis o que hoje surpreende: não havia necessidade de sair à cata de público para ouvir os conferencistas que honravam, com sua presença, a nossa Faculdade. Apinhavase o salão do vinte-e-um: gente sentada nas janelas e no chão, na ponta dos pés, ou de meia-cara, às portas, nos corredores e nas sacadas.

Não, ninguém se enganava. Era transparente... Com vaidosa suficiência, o diretor avaliava o apetite com que jovens e menos jovens invadiam o auditório. No antegozo do prazer de apresentar-lhes seu convidado, levantava-se lentamente, aguardava que se fizesse silêncio e, então, solene, oficiava...

Advirta-se contudo: Veloso não se punha a ruminar façanhas. Nem ficava a degustar a notoriedade alcançada pela sua escola por ocasião de um ciclo de estudos, ao lançamento de uma revista ou diante da ressonância obtida pelos concursos de cátedra, anunciados nos jornais e assistidos com deslumbramento por público estranho aos nossos corredores.

Nada disso. Para que a sementeira não morresse no grelo, seguia impávido. Abria a burra e comprava livros a mancheias: toda a Patrística, os Pré-Socráticos, a Pléiade, Websters, Larousses, Auletes e Morais, as coleções todas dos Clásicos Castellanos, do Fondo de Cultura Económica, da Gallimard, da Gredos, da Aguilar, da Losada e da Espasa-Calpe, da Oxford e da Cambridge, da Suhrkampf, dos Mondadori, volumosas enciclopédias e dicionários, Shakespeare completo e encadernado, todo Voltaire e todo Dante, obras raras, raríssimas. Tudo! Incluído o Dicionário da Língua Mosquito.

Olímpico, indiferente à grita dos chefes do Departamento de Pessoal e do tesoureiro Alexandre (ex-aluno da Universidade de Lovaina), o pródigo varão não fugia à responsabilidade. Porque não pedia, dirigia. Não discutia, comandava. E acenava, irônico, com a sempre adiada federalização, quando todos ganhariam muito bem e seriam felizes para sempre.

Quem o viu e conheceu de perto, não me desmentirá.

Tivemos a sucedê-lo na direção da Faculdade o ponderado, rigoroso e culto Antônio Camilo de Faria Alvim. Muito lhe devemos. O professor Alvim imprimiu à sua 
gestão o cunho do círculo mágico do uai, a Minas profunda. Na discrição, escondia sua qualidade maior.

Embora os separasse a distância que vai dos caminhos e veredas do grande sertão às "mil datas minerais, de lavras, lavras e mais lavras", foi sob a inspiração desses dois mineiros, o de Montes Claros e o do Mato dentro, que nossa Faculdade se abriu para o mundo e fundiu-se aos noventa por cento de ferro das calçadas.

A Arthur Versiani Veloso e à sua Velosofia coube o sonho impossível da criação, em Minas, de uma verdadeira universidade. Entanto, de não menos áspera tarefa haveria de incumbir-se Antônio Camilo de Faria Alvim: a de torná-la mineira, a de afeiçoá-la ao nosso jeito mineiro de ser.

O essencial nessa sucessão de notáveis, quando temperamentos tão diversos se empenham, à luz de um conceito de cultura, na formação da juventude, é que se corroboram e se identificam o ideal de progresso e a fé inabalável no conhecimento.

Nesse delicado balanço, tudo se encadeia numa evolução coerente: à resposta impaciente às necessidades da natureza humana, a grave consciência da sua vulnerabilidade acaba por trazer, com a vocação do bom senso (e foi o que ocorreu), o equilíbrio da lucidez.

Pois é. O tempo passou. Perdido o privilégio da infalibilidade, as Infalíveis tomaram rumo próprio, como qualquer mortal. Feita a opção pelo ensino superior, houve quem mudasse com a escola para o prédio novo, só para nós, nos altos do Santo Antônio.

Mas logo veio a renúncia de Jânio Quadros e veio o Ato Adicional com a instituição do parlamentarismo, a que se seguiria a restauração do presidencialismo com João Goulart no poder e sua visita a Belo Horizonte, a convite de Orlando M. de Carvalho, nosso reitor, para a inauguração da nova Reitoria no terreno da futura cidade universitária.

Entretanto ... veio, também, a greve do "terço" 12 e veio o 31 de março de $64 \ldots$

Enquanto isso, os americanos faziam guerra no Vietnã, os estudantes de Berkeley faziam amor no gramado do campus, os Black Panters contestavam, Woodstock acontecia e os événements de mai 68 viravam pelo avesso a quinta República francesa...

O resto? "Littérature ... cette bêtise."

Voltemos ao Acaiaca.

Não, não havia novela das oito... Haveria, talvez, raros aparelhos de televisão e alguns "televizinhos". Mas não me lembro, à nossa volta, de videotas nem de noveleiros.

José Olegário, vivo, falávamos, com Regina, de Bela Bartok, das cantatas de Bach e de Mignone. Na companhia de João Camilo Castilho, colega das Ciências Sociais, colega e amigo, mais tarde marido de Maura Borges de Andrade, Infalível, alongávamos nossos encontros, depois do curso de Béguin, no Acaiaca, dissertando e discutindo sobre o existencialismo francês ou, no Instituto de Educação, com Agostinho de Campos, aparteando-o, à saída, e descendo com ele à Praça 7, até o hotel onde se hospedava... Quando tratávamos de política, o expert era José Nilo Tavares, claro. Mas se o assunto era pintura, tínhamos à mão nosso Toulouse-Lautrec, o querido Pimenta, Pimentinha,

${ }^{12}$ Um despautério. Os alunos, em greve, exigiam um terço de representação discente na congregação da Fafich. 
autodidata prodígio, companheiro para o que desse e viesse, não importava hora nem programa.

Cada coisa a seu tempo. E tínhamos tempo para tudo. Como nos sobravam voz e fölego, corríamos, à noite, aos ensaios do Teatro Universitário, do Coral e do Madrigal Renascentista... Era quando revíamos a variada fauna das unidades da UFMG, do Conservatório e da Guignard.

É certo que Belo Horizonte deve preservar, nos seus anais, notícias e recortes sobre a grandiosa encenação pelo TU da tragédia lírica de T. S. Eliot, O crime na Catedral. De acontecimento intelectual e social, essa montagem universitária, com Marzano como metteur-en-scène e Magnani na regência do coro, se transformaria em divisor de águas na história do teatro em Minas.

Apoteótica, impressionante, a representação era tão intensamente vivida, tão verossímil, que Carlos Kroeber, envultado no arcebispo da Cantuária, fazia persignar a platéia que lotava o auditório do Instituto de Educação: a fala de Thomas Beckett empolgava e fecundava a consciência e a fé. Uma interpretação à altura do imenso talento do nosso colega.

Por tudo isso, e mais ainda, quem não cantasse no Coral nem fizesse sequer uma pontinha em Our town, de Thornton Wilder, não ficava a subir Bahia e descer Floresta... Buscava diversão. Ia dançar no DCE.

As Infalíveis, tínhamos, no térreo, o Cine Acaiaca. Sábado à tarde, o professor Morais nos dispensava mais cedo para a sessão das quatro. Descíamos para assistir aos musicais da Broadway e aos filmes do neo-realismo italiano - Arroz amargo, Rosa tatuada, Ladrão de bicicleta, Roma, cidade aberta. Se éramos fãs de Gene Kelly e de Sinatra, também cultuávamos Anna Magnani, Giulietta Masina, Silvana Mangano, De Sica, Mastroiani, Gazman...

Nesse trem de vida, nem éramos, os alunos, estudantes típicos de uma Faculdade de Filosofia, nem nossos professores se comportavam, tampouco, como sábios de plantão. E o que era melhor: eles nos ensinavam o que não nos ensinavam.

Empossado na cátedra de Língua e Literatura Espanhola, Eduardo Frieiro foi o pioneiro dos estudos hispânicos em Minas. Comprova-o sua notável bibliografia. Uma alteração no currículo desses estudos na Faculdade Nacional de Filosofia da Universidade do Brasil, ainda com sede no Rio, antes, portanto, da mudança da capital, determinaria, ipso facto, o desmembramento e reestruturação da cátedra em todas as unidades universitárias federais.

Tudo se fez com grande transparência, a fim de dar ao poeta Manuel Bandeira, doente crônico e falto de recursos, um cargo no Ensino Superior. Carlos de Lacerda, deputado e político influente, bateu-se enfaticamente, como só ele era capaz de fazêlo, pela criação da cátedra de Literatura Hispano-americana.

Não foi outro o motivo pelo qual se criou, também em Belo Horizonte, um novo cargo, com novas atribuições. Cabendo a Eduardo Frieiro a escolha entre o ensino de Língua e Literatura Espanhola e o de Literatura Hispano-americana, optou pela segunda.

Desmembrada a cátedra, sairíamos ganhando: tivemos o privilégio de ter, como professores, José Carlos Lisboa, no primeiro e segundo anos, e Eduardo Frieiro, no terceiro 
ano.

Logo à primeira aula, o professor Lisboa, que cumulava as funções de professor da disciplina na Faculdade Nacional, e ministrava o mesmo curso em Belo Horizonte, duas vezes por mês, se fez acompanhar de um jovem assistente, o professor Fernando de Freitas.

Tímido, um tanto gauche, de uma solicitude minuciosa e irritante (aos nossos olhos), Fernando de Freitas carregava a pasta do professor, limpava a mesa e o quadro negro, antes de puxar uma carteira e sentar-se à parte, preservando distância honrosa do mestre ao mesmo tempo em que se mantinha inacessível aos estudantes.

Buenos días e Hasta mañana eram as únicas palavras dele ouvidas em duas horas de aula, nos dois dias consecutivos em que o professor titular passava entre nós. A exemplo de aluno atento, ou simples ouvinte, Fernando de Freitas nos parecia infeliz Sancho Panza, a serviço do Quixote desempenado, todo huesos.

Logo à primeira aula, soubemos a que viera. Sem mover músculo, advertiu-nos, apenas: "De cada golpe les doy un verso". E, então, numa dicção castigada, do mais redondo e sonoro castelhano, ditou-nos um poema de Garcilaso.

Ninguém disse palavra.

Foi assim que começou nossa iniciação à hispanidade. E, também, ao amor e medo. Tremíamos de medo. Mas que alegria descobrir que éramos capazes de situar um soneto numa época, apontar-lhe o autor e justificar nossa resposta! Como penávamos! Ditados os poemas, para análise posterior, cabia-nos citar o autor e a época da publicação. Mas só ousávamos levantar a voz para sugerir uma que outra resposta às perguntas incisivas do magister.

No exercício de assistente, não assistido pelo titular, Fernando de Freitas passaria a ministrar-nos aulas de língua: verbos, verbos e mais verbos. À sua constrangedora timidez, correspondíamos com timidez e meia. Entrávamos mudas e saíamos caladas. No entanto, o castelhano nos ia conquistando. A poco y poco. E chegadas ao segundo ano, o Quixote já não nos atemorizava. Não obstante se observasse, reciprocamente, o tratamento formal.

A lição de rigor do mestre de literatura espanhola, prática e efetiva, era a da importância do estudo de matéria que os estudantes brasileiros tendem a tratar como de ciência infusa. Ao considerar-se instruídos, de nascença, na língua vizinha da mãepátria e dos irmãos do continente, decretam "café pequeno" a leitura dos seus melhores autores.

Corriqueiro nos cursos de harmonia, o uso do enigma na análise da partitura método excelente para a formação de futuros musicólogos, ouvintes e leitores de música - visa à identificação do compositor e da data de criação da peça. Nada mais fácil nem de mais oportuna aplicação nos cursos de literatura...

No entanto, nos idos de $50 / 55$, tal procedimento era, entre nós, bizarria exclusiva das aulas de espanhol. Embora cegos às peculiaridades de linguagem, boleio da frase e vocabulário, tanto quanto alheios à proeminência de escolas e movimentos no estilo de época, não esmorecíamos. Nunca! Espicaçados pelo desejo de acertar, um olho nas reações do Quixote e outro na expectativa do escudeiro, agíamos por eliminação. Natural...

Eis a insolência do método: a moral aplicada em aula se resolvia na busca. Visto que a verdadeira lição não está no acerto, que leva ao prêmio, mas nos desvios a que 
obriga o engano, acabávamos por descobrir o que não passava, muitas vezes, de um "secreto a voces"... "y a voces hay que darlo".

Procurando e errando, errando e procurando, citávamos datas e escolas, sugeríamos nomes e influências, enriquecíamos as questões com sugestões complexas que não só temperavam de complacência a própria ignorância, como despertavam a sensibilidade, a sutileza. Ao projetar sempre mais longe o repto do desconhecido, aprofundávamos a pesquisa e, na formulação do conceito, o teor das reflexões.

Embora não atinássemos com tal desdobramento, era notória a lição humana do nosso afã. Ali mesmo se completava e corrigia-se o que os nossos sentidos adivinhavam. Ensinando-nos literatura, o mestre nos levava a entender que nem tudo o que se vê é o real e que entre o que se pensa e o que se escreve há o espelho de Alice de permeio...

Sem que se excluísse a utilidade imediata de ler sofrendo (no sentido primitivo), a cada tentativa de solução do enigma sucediam cortejos de argumentos. E nesse jogo infinito, de alusões, referências, associações, emergiam teses e hipóteses até que, afinal, déssemos com sínteses coerentes, fora de polêmicas e batalhas de idéias.

Nossa escola, "risonha e franca", tinha astúcias e reinações que nos salvaram da selva e nos conduziram à dritta via.

Diante dos meus próprios alunos, retomei, anos mais tarde, à semelhança do que nos ensinara Spinelli, o longo itinerário que vai do Lasciate ogni speranza voi ch'entrate até o Paraíso. Descobri, então, à sombra de Dante, que a voz dos mestres nos acompanha e exorta, de círculo em círculo, caminhos de dentro e de fora. E quando esse mesmo eco se converte em letra de forma, não é por mero sortilégio que a página escrita os desperta para a vida.

É o que venho sentindo ao ler e reler a obra de Eduardo Frieiro, Mário Casassanta, Vincenzo Spinelli, Aires da Mata Machado Filho, Orlando de Carvalho, José Lourenço de Oliveira, José Carlos Lisboa, Alaíde Lisboa de Oliveira.

Não só pela riqueza e diversidade da vivência que aí transpira, em confronto com o que foi, com o que poderia ter sido e que não foi, a presença daqueles com quem nos defrontávamos na sala de aula ganha nova expressão. À medida que corrigimos e emendamos o retrato original, seus traços se avincam e projetam-se em novas dimensões.

Indo mais longe, é certo que uma abordagem psicanalítica não deixaria oculto, por exemplo, o temperamento cético e espinhado de Frieiro, a vocação monacal de José Lourenço de Oliveira, a ranhetice de Aires da Mata Machado Filho, a visão amena da humanidade de um Mário Casassanta ou a vivacidade petulante de uma Alaíde Lisboa.

No caso de José Carlos Lisboa, a verve provocadora e o instinto histriônico parecem empurrar o autor para situações dramáticas. Tudo quanto escreveu o nosso professor traz a marca do homem dos bastidores da cena. E o que já se insinuava nas suas lições adquire forma efetiva nos seus escritos: desde os estudos sobre o teatro de Cervantes e Tirso de Molina, como o ensaio primoroso sobre a rainha Isabel, a do bom gosto, à visão melancólica dos filhos partidos, os conflitos na casa do bode e as aventuras de Macário.

Numa insistente adesão à vida, ao real, o escritor não escapou ao grande teatro do mundo, onde se intrometia, sempre, o seu duplo. De modo muito pessoal ia ele assimilando ao escrito o que era e o que o comovia. A sua obra tem, por isso, o sabor de 
testemunho pessoal, de crônica, tal como se, espectador atento, nos viesse apresentar a descrição elegante e precisa do que lia, do que via e dos papéis interpretados.

Eis o que confere a José Carlos Lisboa perfil particular: além de contribuir para explicar-lhe a vida, sua obra justifica suas inclinações e seus questionamentos, sua vocação, seu trabalho, sua carreira profissional. $\mathrm{O}$ escrúpulo com que nos guiava pelos labirintos da ficção e da poesia, obrigando-nos a escudrinhar o texto para descobrir-lhe o autor, é o mesmo com que trata seus enredos, com o faro apurado do dramaturgo que se diverte em criar armadilhas, tropeços e suspense para quantos se iniciam no mistério da criação.

E tudo isso nos foi revelado, das 10 às 12 da manhã, diante do quadro negro, numa sala de vinte metros quadrados. Vivíamos a Utopia. Um breve instante da eternidade.

Não será difícil justificar a razão por que escolhemos, para paraninfo, o Professor de Literatura Francesa: rigorosamente acadêmico, sóbrio e ponderado no falar, Orlando de Carvalho aliava, à maravilha, apreço e formalidade. Manifestava simpatia na medida certa: sabia ser amigo sem afronta às convenções nem à boa norma que regiam suas relações com as "Infalíveis".

Não obstante a aura que o cercava, não nos sentíamos, é certo, diante de um scholar. Vale dizer, o especialista versado no trato de um tema ou inteiramente dedicado a um domínio do saber. No nosso caso, a literatura francesa.

Socorriam ao nosso professor outros e mais raros talentos. O largo descortino da história das idéias, a bem nascida segurança e o saber de experiência depuraram-lhe a versatilidade e o cosmopolitismo de aristocrata afeito ao humano, ao demasiadamente humano.

Indene aos $90 \%$ de ferro das calçadas, eis o que lhe dava suporte e firmeza: o esprit de finesse. E era o esprit de finesse que não lhe permitia sucumbir à rigidez geométrica. Se não aprendemos, nas suas aulas, a entender Mallarmé, fomos eficazmente informados das astúcias dos plaideurs...

Que nos propunha o Mestre do Direito?

À luz da linguagem metafórica do Setecentos, Racine desvendara-lhe os enigmas das figuras capciosas, ao gosto dos medalhões da magistratura - les gens de robe. Inspirado nas sutilezas da jurisprudência e do cânon jurídico, que fazia ele? Precavia-nos contra a afetação da ciência retórica.

Se nos faltou, no curso de literatura francesa, a análise da alma romântica e do sonho, à maneira de Albert Béguin, ou o estudo do texto, à Roland Barthes, tivemos, em contrapartida, amplas reflexões sobre o encadear dos movimentos literários, vastos panoramas dos entrechoques de culturas. Não lemos Appolinaire; o que é lastimável. Mas aprendemos a afeiçoar o olhar às estações do ano para distinguir, em Paris, o nascer, do pôr do sol. Graças a uma anedota sobre Lygia Clark, às voltas com a escolha de uma janela para o nascente, passamos a entender a simetria solar e a sofisticação do nãoobjeto... Isso não é pouco. 
Ao resgatar o ido e o vivido na Faculdade de Filosofia, vejo que o grande mérito dos seus fundadores foi justamente esse: o de desvelar-nos, à luz do saber de experiência, uma visão cabal do mundo. Mundo vasto e alheio, mas de opulenta representação científica, histórica e literária.

Aí está. Em vez de encerrar-se em clausura, esse descortino haveria de desdobrarse ao longo dos anos, oferecendo a cada qual o privilégio de urdir, à sua vez e medida, a teia infinita do conhecimento. Não há negar. À semelhança do que nos ocorre, gente humana, tal metamorfose faz que obras-mestras se alterem e se amoldem ao sabor do acaso e da necessidade. Num constante enovelar de sonhos e fantasmas a textos lidos, esquecidos, alguma vez lembrados - a alma demudada! - deparamo-nos no passado com o que foi presente.

Não era esse o preceito de Rousseau?

Claro que não me cabe apreciar nem os efeitos nem o alcance dessa diligência pessoal. Cabe-me contudo admiti-la. Quem escapa ao mergulho no passado? E quem, ao assalto das lembranças, consegue furtar-se ao resgate do tempo perdido?

Tão objetivamente quanto possível, acredito que a base da minha torre de papel se assenta nessa rotina universitária, de livros e mais livros, professores e colegas. Tanto no meu trabalho, solitário e independente, quanto no ócio com dignidade, sei que os valores morais e intelectuais dessa passagem me marcaram com o selo da fraternidade e do respeito mútuo.

Voltemos à cátedra de Literatura Francesa.

A primeira vez em que deixamos as salas de aula do edifício Acaiaca, para acompanhar um professor num giro extramuros, foi atendendo a convite de nosso professor para "conhecer, por dentro, uma redação de jornal".

$\mathrm{Na}$ qualidade de diretor e fundador de O Correio do dia, Orlando de Carvalho guiou-nos nessa visita, explicando, passo a passo, a transformação do evento em notícia, do fait divers, em manchete. E preocupou-se, com escrupulosa minúcia, em assinalar os infinitos percalços enfrentados pelos profissionais da palavra na luta pela livre expressão das idéias. Também ali nos deparamos com o catedrático de Literatura Francesa, imbuído do pensamento do século das luzes, leitor de Diderot e de Voltaire.

Foi o que entendi, ingênua e pouco versada no trato das ideologias: incapaz de imaginar que estivéssemos diante do fundador do mais prolífico e respeitado periódico político da nossa América, a Revista Brasileira de Estudos Políticos, guardei apenas, do seu discurso, a gloriosa lembrança de que o nosso mestre erguia a sua tribuna onde bem lhe aprouvesse, até mesmo num parque gráfico... Não nos fazia o panegírico das mais modernas impressoras off set da capital de Minas?

Iniciados no jargão jornalístico e tipográfico, aprendemos, de visu, o que eram composição, revisão, diagramação, lay out, caixa baixa e alta, versais e versaletes e assistimos, siderados, à impressão da página do matutino que a cidade inteira só leria no dia seguinte...

Ainda a convite de Orlando de Carvalho, que ciceroneava três universitárias argentinas, visitamos a cidade de Sabará, detendo-nos na capelinha de Nossa Senhora 
do Ó, onde Jair, restaurador mineiro - discípulo de Edson Motta - dirigia os trabalhos de recuperação da mesma capela. Nesse dia, o nosso professor, ouviu, calado, tão aplicadamente quanto as alunas, a aula do futuro mestre na arte da restauração.

Mas o nosso aprendizado das coisas do mundo não iria interromper-se às fronteiras do Estado. Ao saber da tournée da Comédie Française à América do Sul, e de sua passagem pela capital do país, o Professor Orlando empenhou-se para que a notável mise-en-scène de Jean-Louis Barrault sucedesse à leitura, em classe, das peças de Molière e de Corneille, ilustração magistral dos requintes do classicismo francês.

Mercê da obstinação do catedrático, a Faculdade destinou verba especial para o pagamento dos ingressos e pudemos assistir, no Rio de Janeiro, a três apresentações da troupe do Français, cuja vedette era nada mais nada menos que Madeleine Renaud. A senhora do Prof. Orlando, D. Lourdes Pinto de Carvalho, nos fez companhia. Embora não se hospedasse no Hotel Ipanema (onde tínhamos reserva de aposentos) o casal esteve ao nosso lado na platéia do Teatro Municipal.

Quem ficaria insensível a tão expressivas quanto elegantes demonstrações de estima? E que opção restaria aos alunos do Curso de Letras Neolatinas, pour bien fermer la boucle, senão a de eleger o Professor de Literatura Francesa para paraninfo? Isso ocorreria ao final do ano letivo de 1955. Fomos recebidos por D. Lourdes e Orlando de Carvalho no salão de sua casa, na rua Pernambuco, 909, onde pontificava uma belíssima harpa. Ali conhecemos e admiramos o acervo da sua biblioteca, cujas estantes, de jacarandá da Bahia, copiavam o risco e a disposição da velha biblioteca da Universidade de Coimbra. Esse, o quadro em que emolduramos, para futuras memórias, nossa despedida à arte de ensinar e às regras de bem viver.

Posso dar testemunho do efetivo interesse do Professor Orlando pela carreira dos alunos, ora incentivando-nos a prosseguir os estudos fora do país, ora convidando-nos os de pena fácil e gosto pela literatura - a enviar colaborações ao Correio do dia. Foi assim que Magda Becker Soares, Glaura Vásquez de Miranda e também eu publicamos nossos primeiros artigos na imprensa de Minas.

Professor Convidado pela Universidade de Nashville, Orlando de Carvalho iria aos Estados Unidos em 1966 para um extenso circuito universitário, leste a oeste, de ampla ressonância. Sempre acompanhado de D. Lourdes, passaria pela Universidade de Indiana, onde os recebi. Três anos depois, numa de suas peregrinações oficiais aos países da Europa, o ex-reitor da UFMG veio a Paris para as sessões da UNESCO, de que era Conselheiro. Nossa agenda o confirma. Ali cruzamos, numa feliz coincidência, com um dos seus ex-alunos, o orador da turma de 1955, Delauro Baumgratz.

"O mundo é pequeno!", haverá quem exclame. Mas o tempo, a exemplo da luz, apenas limita, ou amplia, no curso da vida, suas primeiras refrações. $\mathrm{O}$ acaso nada faz além de alongá-las: o que comprova o inesperado encontro. No exercício de funções que excediam, pela sua importância, nossas próprias aspirações, figurávamos ali, tão longe do Brasil, as expectativas do mestre.

Não, o bom mestre não é aquele que ensina. Apenas... Não é, tampouco, aquele que confere títulos; é, sim, aquele que instrui os discípulos para o mundo. Pois se ensina, "ensina outra coisa que o que ensina". E atente-se! Há mestre sem discípulos, mas não há discípulos sem mestre... 
Concluo, repetindo-me, com uma citação de Georges Gusdorf: "O ensino mais alto do mestre não está no que diz, mas no que não diz". ${ }^{13}$

É tarde. Muita gente se foi, cartas se extraviaram e o silêncio responde agora ao vozeio alegre das tardes de sábado. Precedida pela sentença intemporal "De cada golpe les doy un verso", resta-nos a lição de Mairena:

"Tales los hombres sus fortunas vieron: en un día nacieron y expiraron, que, passados los siglos, horas fueron."

A

13 “[...] il enseigne autre chose que ce qu'il enseigne. Le plus haut enseignement du maittre n'est pas dans ce qu'il dit, mais dans ce qu'il ne dit pas" (Georges Gusdorf, Para que professores?). 